\title{
Lessons from Payments for Ecosystem Services for REDD+ Benefit-Sharing Mechanisms
}

\author{
Lasse Loft, Pham Thu Thuy and Cecilia Luttrell
}

\section{Key lessons from PES for REDD+ benefit sharing}

- Where benefits and costs accrue at different scales, financial intermediaries are needed to facilitate relations between global-scale buyers and local-scale providers of carbon sequestration and storage. These intermediaries can help to collect and distribute payments and to promote the scheme to potential beneficiaries.

- The benefits distributed should compensate for the transaction, opportunity and implementation costs incurred by stakeholders for providing ecosystem services. Therefore, calculating the costs and understanding who incurs them are essential for benefit sharing.

- Targeting benefits according to a set of criteria that match the objectives of the specific mechanism increases the mechanism's efficiency.

- As the level of performance-based payments may not be able to compete with the opportunity costs of highly profitable land uses, performance-related benefit-sharing mechanisms should be focused on areas with moderate opportunity costs.

- Benefits should be divided into upfront payments to cover startup costs and to give an initial incentive for participation, and payments upon delivery of ecosystem services to ensure adherence to conditionality.

\section{Introduction}

Reducing Emissions from Deforestation and forest Degradation (REDD+) is designed as a performance-based mechanism that will provide financial compensation to developing countries for fully measured, reported and verified emission reductions relative to baseline levels (Wertz-Kanounnikoff and Angelsen 2009; Karsenty et al. 2014). The implementation of REDD+ projects and policies is expected to generate benefits, both monetary and nonmonetary. For most countries carrying out REDD+ activities, one of the most pressing tasks is to develop governance structures to distribute these benefits among stakeholders in an effective, efficient and equitable manner (Luttrell et al. 2012, 2013; Pham et al. 2013a). Benefits can be shared on a 'vertical axis' from national via regional to local levels and on a 'horizontal axis' within and across communities, households and other local stakeholders (Lindhjem et al. 2010; UN-REDD 2011).

This info brief aims to provide policymakers and practitioners with policy options and guidance to improve the design of benefit-sharing mechanisms for REDD+ by looking at lessons learned from the implementation of Payments for Ecosystem Services (PES) schemes. We define PES broadly as the conditional "transfer of resources between social actors, which aims to create incentives to align individual and/or collective land use decisions with the social interest in the management of natural resources" (Muradian 2010, 1205). A key feature that differentiates PES from other economic instruments is conditionality, that is, payments are made only if the actual service or the land use providing the services is delivered.
This brief discusses ways to improve the effectiveness of benefit sharing in a multilevel governance structure and to reduce the costs of REDD+ benefit-sharing mechanisms. We explore ways to motivate both buyers and sellers of ecosystem services to participate in performance-based REDD+, and address the question of how to balance multiple objectives of REDD+ benefit sharing.

For this review, we conducted an ISI Web of Knowledge search, and included grey literature for in-depth case study analysis. The results and references of the case study analysis are presented in the annex.

\section{Enhancing effectiveness of benefit sharing}

\subsection{REDD+ benefit sharing requires intermediaries in a multilevel governance structure}

An important question for REDD+ benefit sharing concerns the governance level at which benefits should be distributed. Experiences with PES schemes reveal a need to identify the scale and spatial distribution of providers (sellers) and beneficiaries (buyers) of ecosystem services when planning management interventions (Naidoo and Ricketts 2006; Costanza 2008; Fisher et al. 2009). Such interventions include benefit distribution and cost compensation, as well as the design of governing institutions. In cases where providers and beneficiaries of an ecosystem 
service are at the same spatial level, institutions at that level can collect and distribute payments, as is the case for most PES schemes related to watershed management (for example, Lam Dong Province in Vietnam (Tan 2011; To et al. 2012), Cidanau watershed in Indonesia (Leimona et al. 2010) and FORAGUA in Ecuador (Goldman-Benner et al. 2012). In contrast, services such as biodiversity, landscape beauty and carbon sequestration are managed locally but the beneficiaries are global; in these cases, the benefit-sharing mechanism needs to connect global beneficiaries with the local providers through intermediaries, to ensure the transfer of monetary benefits. An example is the UNFCCC Clean Development Mechanism, which links the providers of the ecosystem service of carbon sequestration, achieved through afforestation and reforestation activities in developing countries, with the industrialized countries that benefit from enhanced uptake of $\mathrm{CO}_{2}$

Intermediaries typically transfer knowledge, negotiate and/ or communicate the offered payments, make contracts with interested providers, monitor compliance and make payments (Pagiola and Platais 2007; Laurans et al. 2012). However, few data are available on the effectiveness of the services provided by intermediaries and the impacts of their interventions. Pham et al. (2010) found that the effectiveness of PES and its benefit-sharing mechanisms greatly depends on the following:

1. the quality of intermediaries' participatory work

2. the level of political influence over intermediaries' activities

3. the neutrality of intermediaries

4. the capacity and accountability of each governance level in handling financial transactions and the costs incurred by such multilevel governance.

Most government intermediaries are state agencies that act on behalf of the end users by paying for the services provided or distributing payments to service providers (Engel et al. 2008; Pattanayak et al. 2010). Public administration can support the scheme by collecting payments and distributing the benefits to ecosystem service providers directly, such as the role that the Ministry of Finance plays in China's Sloping Land Conversion Program (Bennett 2008), or through involvement in trust fund models. For example, the Costa Rican PES program is managed by the National Fund for Forest Financing (FONAFIFO), whose responsibilities include securing agreements with water users to pay for watershed conservation (Pagiola 2008). In Son La Province in Vietnam, the Provincial Forest Protection and Development Fund arranges contracts with ecosystem service providers and signs contracts with buyers on the providers' behalf. It then acts on behalf of the providers to collect payments from buyers and distributes these payments among the providers. In addition, the fund monitors the provision of ecosystem services (Tan 2011; To et al. 2012). In Brazil, the Amazon Fund provides financing for project implementation (Hall 2008) and the state of Amazonas created an independent private nongovernmental institution (FAS) to manage the Bolsa Floresta program (Pereira 2010).

Using existing government administrative structures to set up PES schemes can reduce transaction costs (Vatn et al. 2011). However, the operational costs of trust funds either within or outside government administrative structures can be high (Spergel and Taieb 2008) and often absorb a large proportion of PES payments.
For example, in Son La Province, the distribution of PES payments and administration of the Provincial Fund involves more than 3500 staff members and absorbs more than $10 \%$ of total PES revenue. Weak financial management capacity and corruption at various government levels have also delayed the PES process and resulted in misuse of PES revenue (Pham et al. 2013b). An analysis of 55 conservation trust funds suggests that having multistakeholder governance bodies can reduce the risk of corruption and political influence over spending decisions (Spergel and Taieb 2008).

Buyers often create their own intermediaries when they are the direct users of an ecosystem service (Wunder et al. 2008). As examples from Tanzania, Vietnam and Indonesia illustrate, these intermediaries are often nongovernmental organizations (NGOs) that promote the interests of the poor, protect the environment, provide basic social services or undertake community development. In Vietnam, Pham et al. (2010) found cases where poor-quality participatory work by nongovernmental intermediaries meant that local people had little involvement in designing the benefit-sharing mechanisms, which reduced the likelihood of the mechanisms being locally adapted or equitable. Intermediaries that are outsiders often cannot capture and represent local interests, but few local intermediaries have the capacity to act on behalf of local interests. Connecting local providers of the ecosystem service of carbon sequestration and storage with beneficiaries across the globe requires government and/or private intermediaries at various scales. It is important to ensure that intermediaries at all levels have high-quality management skills and to build the capacity of local-level intermediaries.

\subsection{Monitoring and evaluation of PES}

An essential element of performance-based benefit-sharing mechanisms under REDD+ and PES is monitoring the provision of the ecosystem service and the conditional disbursement of revenues (Engel et al. 2008; OECD 2010). As in PES, REDD+ benefit sharing can take the form of an output- or performancebased payment system, in which the landholders are (financially) rewarded for the actual performance in terms of empirically verified provision of the ecosystem service (higher forest carbon stocks in relation to reference emission levels) (Pagiola et al. 2005; Luttrell et al. 2012). However, it is often impossible to make payments based on monitored outputs because the provided ecosystem service cannot (or can only with prohibitively high costs) be fully measured and directly linked to the chosen landuse option (Rørstad et al. 2007; Engel et al. 2008; Pattanayak et al. 2010). Advances in science and remote sensing have made carbon sequestration and storage easier to measure and monitor than, for example, biodiversity and watershed services (Hall 2008; Pattanayak et al. 2010; Pereira 2010; Conceicao 2012; Alston et al. 2013), but in many cases monitoring is conducted only loosely or not at all (see also Wunder 2007). Reasons are the lack of available and reliable data on land tenure, forest quality and quantity, high cost monitoring technology, low human capacity, and poor information exchange and coordination among sectors and government agencies (To et al. 2012; Alston et al. 2013; Pham et al. 2013b). In some national PES programs, such as in the case of Vietnam, a national monitoring and evaluation system with credible procedures that guide monitoring and evaluation is completely absent. 
In addition to monitoring the provision of ecosystem services, PES schemes require monitoring of further contractual provisions, such as the timely provision of payments. This form of monitoring is often challenging because of weak law enforcement, low willingness to pay among buyers and the lack of involvement of local people in designing benefit-sharing mechanisms. A lesson from PES for REDD+ benefit-sharing mechanisms is that a tradeoff exists between precision in monitoring ecosystem services and the costs of measurement.

\section{Enhancing the efficiency of benefit- sharing mechanisms}

The costs of performance-based benefit-sharing mechanisms such as REDD+ take various forms: transaction costs of negotiations, contracting, administration, monitoring and enforcement of ecosystem service provision, and costs of incentivizing land-use change (assumed to be equal to or greater than opportunity costs) (Wunder 2005, 2007; Vatn et al. 2011). If the funds available through the benefit-sharing mechanism fall short of these costs, performance-based benefit-sharing mechanisms for REDD+ are unlikely to achieve their stated objectives (Karsenty et al. 2014).

\subsection{Reducing the transaction costs of benefit- sharing mechanisms}

Transaction costs are a major burden for PES in developing countries (Pirard and Billé 2010). Studies from Costa Rica, Cambodia, Mexico, Tanzania, Mozambique and Ecuador found that transaction costs can total up to $66 \%$ of the income generated through the schemes; the costs for REDD+ are expected to be comparable (Alston et al. 2013). As experience with PES shows, transaction costs are influenced by the following:

1. the number of actors involved in the scheme and the size of the area of the program, as transaction costs are lower when there are fewer actors in relation to the size of the scheme

2. the clarity of property rights over the ecosystem service itself or the land providing the ecosystem service, as clarity of property rights reduces the costs of determining landowners and reduces liability risks

3. the physical and economic characteristics of the ecosystem service (scale of benefit provision and degree of public good characteristics), as the more public good characteristics the ecosystem service has, the more costly it is to exclude actors without use rights

4. the governing institutions of the PES program, as the use of existing governance structures reduces costs (Wunder et al. 2008; OECD 2010; Alston et al. 2013).

Options identified in PES schemes to reduce costs include bundling large numbers of smallholders into groups (as done in Son La and Lam Dong Provinces in Vietnam), introducing a minimum area as the criterion for eligibility to enroll in the program (Wunder and Albán 2008) and making use of existing models and instruments for natural resource management (Nelson et al. 2009; Alston et al. 2013). For example, in the case of Terrat in the Simanjiro Plains of Tanzania, the contractual provisions and structure of the PES agreement built on existing agreements between private companies and a neighboring village (Nelson et al. 2009). In the case of Lam Dong Province, payment distribution was based on an earlier national reforestation program (Program 661 and Program 327) and the Forest Protection and Development Fund made use of the existing system to make contracts with local people.

Given the expense of linking the actual provision of an ecosystem service to a specific management activity, an alternative to the performance- and output-based approaches is to link conditional payments to effort and input (Alston et al. 2013). In this approach, land-use types and land-use changes are used as a proxy for the provision of ecosystem services (Engel et al. 2008; Table 3), and financial rewards are distributed to landholders as long as they carry out activities that are assumed to improve forest conditions and hence enhance carbon stocks. Payments are made on a perhectare basis or are based on other metrics to measure inputs, such as the number of trees planted (Engel et al. 2008). However, input-based monitoring does not ensure the actual provision of the service purchased, which will create possible trade-offs between lower transaction costs and increased effectiveness (Alston et al. 2013). Therefore, input-based monitoring could be an option for a transitional phase until monitoring methods for REDD+ improve and costs fall. Analysis of four PES case studies in Vietnam and responses from interviews in other countries suggest that the combination of techniques such as participatory carbon measurement and remote sensing could reduce forest monitoring costs while strengthening the involvement of local people in PES schemes (Pham et al. 2009, 2013b).

In summary, high transaction costs pose a major challenge for performance-based benefit-sharing mechanisms. Options to reduce transaction costs include bundling large numbers of smallholders into groups of beneficiaries, making use of existing governance structures, and conducting input-based monitoring for a transitional phase.

\subsection{Enhancing the cost-effectiveness of payments through targeted and flexible payments}

In PES, one way to enhance the efficiency of benefit-sharing mechanisms within a tight budget is to target payments according to predefined objectives (OECD 2010). For example, PES can target areas with high provision of ecosystem services, as in the example of Cidanau in Indonesia, where the (potential) contribution to sedimentation was a targeting criterion for site selection (Leimona et al. 2010; Pirard and Billé 2010). If PES objectives include issues related to equity such as poverty alleviation, relative poverty can serve as a targeting criterion.

Targeting criteria can be combined with flexible payments proportional to criteria fulfillment (Engel et al. 2008; Wünscher 2008). As Engel et al. $(2008,671)$ explained:

Fixed payments give high production rents to land owners with low costs of ES [ecosystem service] provision, while those with high costs of ES provision are likely to not participate in the program. Thus, flexible payments equal to (or just above) the individual costs of ES provision would allow larger areas to be included in a PES program for a given budget. The challenge in cost targeting lies in estimating site-specific costs of ES provision, particularly opportunity costs. 
In practice, payments do not always go to the stakeholders targeted according to predefined objectives. In the case of the Equitable Payments for Watershed Services program in Tanzania, for example, the participation of targeted poorer households may have been limited because these households depend on their land for their livelihoods and so had less land available to include in the scheme (Branca et al. 2012; Lopa et al. 2012). For REDD+ benefit sharing to be efficient and achieve its objectives, therefore, it is important not only to identify the specific objectives of the benefit-sharing mechanism and set targeting criteria accordingly, but also to monitor and adapt payments and targeting criteria where necessary.

\subsection{Bundling of payments for different ecosystem services}

One argument holds that changing land-use decisions will require that the REDD+ benefits distributed to landholders cover both the (opportunity) costs of potential loss of income from alternative use and the costs of actively protecting the land use against external threats (Karsenty et al. 2014). These costs may vary substantially according to such factors as location, soil quality and type of production. It has been observed that "PES programs that reflect ecosystem providers' opportunity costs via differentiated payments are more cost-effective" (OECD 2010, 17). As PES schemes in Son La and other places in Vietnam show (To et al. 2012; Pham et al. 2013b), benefits generated through PES are often unable to match the opportunity costs of other land uses (Wunder 2007).

Instead of designing a PES scheme for a specific ecosystem service paid for by the beneficiaries at the same scale at which that service is provided, a promising alternative to increase the total benefits and match opportunity costs is to bundle payments from several ecosystem service beneficiaries for the simultaneous provision of several ecosystem services across multiple scales (OECD 2010). An example is to combine payments by local beneficiaries for watershed services with international carbon finance, or with national or international payments for habitat conservation. Bundling can further reduce transaction costs because a single institution could administer the program and manage the monitoring, reporting and verification of all the ecosystem services. However, this will require coordination of the collection and distribution of benefits at multiple governance levels.

\subsection{A range of stakeholders incur costs}

The costs and benefits of REDD+ implementation occur at different levels and to different stakeholders. For example, costs are incurred by the following

1. the country as a whole, that is, "any costs that are perceived anywhere within the country, net of any benefits that are received anywhere within the country, omitting any costs and benefits that accrue outside the country" (Pagiola and Bosquet 2009, 5)

2. individual actors

3. government agencies, as "the government will usually bear little or none of the opportunity costs, but it will often bear the bulk of the costs of implementation ... and of the transaction costs" (Pagiola and Bosquet 2009, 6).
Therefore, stimulating action through the provision of (net) benefits requires knowing what kind of costs will be incurred by which actors and at which level (Luttrell et al. 2013). However, in none of the PES case studies reviewed for our focus countries has a cost differentiation between levels and stakeholders been performed (see annex and similar conclusions by Wunder et al. 2008; Pattanayak et al. 2010; Alston et al. 2013). Understanding the costs is important for the equitable sharing of benefits and costs among stakeholders.

\section{Motivation for participation in REDD+}

\subsection{Periodic disbursement of a combination of cash, in-kind benefits and capacity building}

The size, type and timing of benefits distributed through performance-based mechanisms in the natural resource sector, such as PES, influence the outcomes in terms of land-use change (Engel et al. 2008; Börner and Vosti 2013). In this regard, PES programs can offer valuable lessons for REDD+ benefit sharing.

Alston et al. (2013) showed that the provision of initial financial benefits upfront (seed) enables landholders to cover the large upfront labor and opportunity costs of land-use change. This suggests that it may be advantageous to disburse benefits in intervals. To ensure conditionality, other schemes provide payments upon delivery of the service and some mix approaches and provide payments both in intervals and for performance. In most of the systems in the case studies reviewed, payments were distributed annually on a per-hectare basis (Table 4).

Cash payments are not the only type of benefit, however. With PES generally in the pilot stage, most programs included capacitybuilding activities, such as training and extension services (Branca et al. 2012; Lopa et al. 2012), and in-kind payments to individuals and communities (To et al. 2012; Pham et al. 2013b). In-kind compensation and capacity building are important as they have been shown to enhance the effectiveness of payment schemes and "may reduce a breakdown in social norms," in contrast to cash payments, which potentially have a crowding-out effect on intrinsic motivations for conservation (Vatn 2010; Alston et al. 2013, 8).

Assuming that PES and REDD+ participants are rational decision makers, they will most likely engage in a program if they receive benefits equal to or exceeding the costs of engagement (net benefits or rent) (Wunder et al. 2008; Karsenty et al. 2014). However, if the emphasis is placed on the equal sharing of benefits regardless of beneficiaries' legal, social or economic status and regardless of the condition of the forest they are paid to conserve, each beneficiary may end up receiving only a small proportion of the total PES payments because they manage only a small area of forest (as seen in Son La, Vietnam) (Pham et al. 2013b). Such an approach does not create sufficient incentives to protect the forest or enhance its quality, which renders it ineffective. Thus, a major criterion for setting the level of benefits is to include some form of cost calculation. In most of the cases reviewed, the benefit levels were set after (partial) cost calculation (Leimona et al. 2010; Pirard and Billé 2010). Wunder et al. $(2008,841)$ conclude that "in practically every case, payments are based implicitly or explicitly on the cost of ES provision, rather than on the value of the ES." The 
exact value of an ecosystem service is often hard to monetize if it does not have a market value, and the decision of a rational land user will depend on the income generated through other land uses, that is, the opportunity costs: "Thus programs that are nominally paying for multiple ES, such as Costa Rica's Payments for Environmental Services (Pago por Servicios Ambientales, PSA), do not pay more for similar activities than programs paying for a single ES, such as Mexico's Payment for Hydrological Environmental Services (Pago de Servicios Ambientales Hidrológicos, PSAH)" (Wunder et al. 2008, 841). For a PES program to achieve its objectives, it requires sufficient and sustainable finance (OECD 2010).

\subsection{Enhancing stakeholder participation in design and implementation}

For REDD+, it is important to "understand what role different actors play in benefit sharing systems, for example in terms of who is making decisions about how sharing occurs" (Peskett 2011, 6).

In a PES scheme where the government acts as intermediary, buyers and sellers alike generally have limited influence on the benefit-sharing mechanism (Tan 2011; To et al. 2012; Krause and Loft 2013). In Vietnam, for example, the government's practice of unilaterally setting the level of payment with limited consultation with buyer groups (water supply companies, hydropower plants) has led to a lack of compliance by buyers. As a result, in many provinces, buyers' willingness to pay is low. Benefit sharing for REDD+ could therefore be enhanced by considering the views of buyers and sellers when setting prices, at the very least by informing them about the basis for determining the price.

Currently, NGOs or government agencies conduct monitoring of ecosystem service provision and payment delivery. However, as the case of Vietnam shows, both buyers and sellers have demanded or expressed strong interest in participating in monitoring and verification. The case of Cidanau, Indonesia, indicates that buyers and sellers prefer multi-stakeholder trust funds, comprising both state and nonstate actors on the management boards, because this increases accountability for management of the funds (Munawir and Vermeulen 2007; Leimona et al. 2010). Transparency through information exchange among actors is important for benefit-sharing mechanisms to be equitable and effective. For example, in Vietnam, Decree 99 requires the national Forest Protection and Development Fund to send annual reports to ecosystem service buyers detailing how their PES payments have been used. However, this task is rarely completed, which weakens buyers' willingness to continue to participate in the PES scheme. Some cases highlight a need for complaints procedures and dispute resolution mechanisms also. When village management boards in Son La were perceived as being not accountable or capable, villagers requested from their village head that payment be transferred to self-formed groups, such as the village police unit or national defense groups (To et al. 2012; Pham et al. 2013b). An example of the inclusion of a local conflict resolution mechanism comes from Bolsa Floresta (Brazil), where ecosystem service providers who breach their contract by failing to conserve forest receive a warning, and must justify their reasons for deforestation to the community association. Those who continue to breach the contract may have the contract terminated (Pereira 2010; Conceicao 2012).

\subsection{Secure rights to the ecosystem services enhance benefit distribution}

In the debate about who should benefit from REDD+, one rationale put forward is that those "with a legal claim or right (whether statutory or customary)" to carbon should be entitled to benefits (see Luttrell et al. 2013 for an overview of these rationales). According to the Cosean theory underlying PES concepts, the market failures behind the under-provision of ecosystem services can be corrected through private transactions (Gomez-Baggethun and Ruiz-Perez 2011). For these transactions, ecosystem services need to be appropriated through the formalization, definition and enforcement of property rights to the service prior to PES implementation (Alston et al. 2013); if not, warned the $\operatorname{OECD}(2010,16)$, "risks associated with, for example, illegal logging or land appropriation will undermine the ability of a landholder to provide the ecosystem service, rendering the PES ineffective." In REDD+, sellers of the ecosystem service of carbon storage could either be those that hold the right to the carbon or those that hold the right to change the land use (Karsenty et al. 2014).

Most PES projects require a certain land use that results in the provision of the ecosystem service. This raises the question of which type of property right (common property or pure private property, usufruct or full ownership) to the underlying ecosystem service stocks and flows (such as the trees, forest or land) service providers must hold to be able to trade the service (Corbera et al. 2009; Vatn 2010). In many countries, property rights to the environmental resources that provide the ecosystem service, or to the service itself, are not specifically defined, and so it remains unclear who has the right to the benefits. Corbera et al. (2007) argued that in the absence of specific legislation on property rights to ecosystem services, property rights to the environmental resources providing the service determine to whom ownership over the services is attributed and hence to whom the benefits from their commercialization accrue. This was the case in many of the PES schemes reviewed; for example, in Tanzania, no specific legislation covered the ecosystem services of soil conservation and habitat provision. In these cases, the property rights to land determined the beneficiaries. For REDD+ benefit sharing, therefore, it will be important to determine whether these rights will be tied to the natural resource providing the services, such as the trees, forests or land, or whether the carbon sequestered and stored in biomass will be treated as a separate asset.

PES arrangements apply to land held in common as well as to private, individual land (Corbera et al. 2007; Alston et al. 2013). An example of PES arrangements on land held in common comes from Tanzania, where village councils have a clear statutory form; they are corporate bodies capable of owning property, taking legal action and entering into contracts with third parties, and they are responsible for managing lands within villages' customary or formalized boundaries (Nelson et al. 2009; Branca et al. 2012; Lopa et al. 2012).

As studies on carbon rights show, in most REDD+ candidate countries, carbon rights will be linked to rights to land and forest use (Cotula and Mayers 2009; Loft et al. 2014, unpublished manuscript). Therefore, government authorities in these countries must deal with the complexity of local land tenure arrangements (e.g. To et al. 2012; Pham et al. 2013a): This complexity is often 
related to conflicting legal systems, with an overlap between de jure and de factor property rights, where formal government or private ownership of land is not enforced and where local ownership is not formally recognized (Alston et al. 2013).

Some functional PES schemes operate despite the lack of fully formalized land titling (Vatn 2010; see also Pirard and Billé 2010; Leimona et al. 2006 for the case of Singkarak), but this raises liability concerns in the case of land-use changes that diminish carbon stocks. Therefore, for REDD+ benefit sharing, it will be important to clarify not only who has the right to benefit from the provision of the ecosystem service of carbon sequestration and storage but also who can be held liable for failure to provide it.

\section{How to balance multiple objectives}

Experience with PES shows that schemes often set multiple objectives, such as the provision of ecosystem services (environmental effectiveness) and reduction of poverty (as an element of equity) (Muradian et al. 2010). It is necessary to state these objectives clearly in terms of the ' $3 \mathrm{Es}^{\prime}$ ' (effectiveness, efficiency, equity), to help guide the "design of the program, enhance transparency and avoid ad-hoc political influence" (OECD 2010, 16).

REDD+ is perceived, first and foremost, as a mechanism that aims to reduce emissions by securing the continued provision of carbon sequestration and storage by forests (Angelsen 2009). Similarly, some authors stress that a primary objective of PES is to provide ecosystem services efficiently and effectively (Pagiola et al. 2005; Engel et al. 2008; Wunder et al. 2008). However, PES schemes often involve an additional emphasis on equity in benefit sharing and livelihoods, as this will strengthen the perceived legitimacy of the program (Corbera et al. 2007; Wunder 2007; Muradian et al. 2010; Miteva et al. 2012; Krause and Loft 2013). A major reason for including these 'side objectives' is to secure political support at the scale of implementation (Wunder et al. 2008), and it has been noted that, in cases in which incomes are improved and poverty is reduced, service providers have an incentive to assist with service delivery rather than to undermine the project: "Ultimately, such assistance reduces the need for extensive external monitoring and helps to reduce transaction costs" (Alston et al. 2013, 7). Therefore, equity should be a central consideration when designing REDD+ benefit sharing.

However, efforts to achieve all 3Es equally will most likely not succeed because of the inherent trade-offs between them (Rodriguez et al. 2011; Muradian et al. 2013), and "fundamental doubts exist as to how much sense it makes to forcedly link conservation and poverty alleviation agendas when trade-offs outweigh synergies" (Wunder 2007, 49). PES schemes are not standalone policy instruments. They tend to be embedded in wider programs and accompanied by other instruments such as legal regulations or welfare programs. Some of these programs are being implemented across government levels, such as Proambiente and Bolsa Floresta in Brazil and PES in Lam Dong and Son La, Vietnam (Hall 2008; Wunder et al. 2008; Tan 2011; To et al. 2012). Given that payments for the provision of ecosystem services have socioeconomic impacts, it is necessary when designing conditional benefit-sharing mechanisms to decide whether to build equity directly into the mechanism, or address it through separate instruments that accompany the mechanism. Either way, REDD+ benefit sharing will need to better link and integrate efficient conservation and social targets, as these determine the ultimate land-use decision.

For REDD+ benefit sharing to have legitimacy and transparency, it is important to clearly define the scope of the benefit-sharing mechanism in national and subnational legislation. Governments in some of the countries examined in this analysis developed a policy foundation for PES, which formed the legal basis for setting up the schemes reviewed; for example, Tanzania passed the Water Resources Management Act (2009) and the Vietnamese government issued Decision 380/QDTTg and Decree 99. Indonesia and Brazil do not have specific policy frameworks for PES, but several laws and policies can be interpreted as providing the basic rules and incentives, such as Indonesia's Water Resources Act No. 7/2004 and Forestry Law No. 41/1999 (Hall 2008; Indrarto et al. 2012).

\section{Lessons for REDD+}

Following are key lessons from PES for REDD+ benefit sharing:

\section{To enhance effectiveness:}

- Set up institutionalized financial intermediaries, to facilitate relations between global-scale buyers and local-scale providers of carbon sequestration and storage, for tasks such as collecting and distributing payments, and promoting the scheme to potential beneficiaries.

- Establish mutually enforcing institutions at various levels from local to national, with a focus on existing governance structures in each country.

- Recognize the need to consider social objectives and the fair distribution of incentives. This can strengthen the legitimacy of the benefit-sharing mechanism and motivate service providers to assist with service delivery rather than undermine the project; this assistance ultimately reduces monitoring costs.

- Divide benefits into upfront payments to cover setup costs and to give an initial incentive for participation, and payments made on delivery of the ecosystem service to ensure adherence to conditionality.

\section{To enhance efficiency:}

- Ensure that the benefits distributed cover the transaction, opportunity and implementation costs incurred in service provision. Cost calculation is therefore essential for benefit sharing.

- Set criteria for benefit distribution that appropriately support the objectives of the benefit-sharing mechanism.

- Monitor payments and targeting criteria and adapt them as necessary.

- Consider input-based payments if output-based payments are not feasible because the costs of measuring service provision are prohibitive.

- Bundle individual or household payments for communities and use existing administrative structures in order to reduce transaction costs.

- Consider issuing supplementary policy instruments, as performance-based payments may not be able to compete with the opportunity costs of highly profitable land uses. Focus benefit-sharing mechanisms on areas with moderate opportunity costs. 


\section{To enhance equity:}

- Allow buyers and sellers to participate in price setting.

- Increase transparency through information exchange among actors.

- Include complaints procedures and dispute resolution mechanisms in the design of mechanisms.

- Define the right to benefit from the ecosystem service and clarify responsibility for service provision.

\section{Acknowledgments}

The authors gratefully acknowledge funds received by the European Commission, NORAD, Ausaid and UK aid. We are grateful to Elena Petkova, whose critical remarks have helped to improve the article.

\section{References}

Alston LJ, Andersson K and Smith SM. 2013. Payment for environmental services: Hypotheses and evidence. Annual Review of Resource Economics 5:4.1-4.21.

Angelsen A. 2009. Introduction. In Angelsen A, ed.. Realising REDD+ National Strategy and Policy Options. CIFOR: Bogor, Indonesia. 1-12.

Bennett MT. 2008. China's sloping land conversion program: Institutional innovation or business as usual? Ecological Economics 65:699-711.

Börner J and Vosti SA. 2013. Managing tropical forest ecosystem services: An overview of options. In Muradian R and Rival L, eds. Governing the Provision of Ecosystem Services. Dordrecht, the Netherlands: Springer. 21-46.

Branca G, Lipper L, Neves B, Lopa D and Mwanyoka I. 2012. Payments for watershed services supporting sustainable agricultural development in Tanzania. Journal of Environment and Development 20(3): 278-302.

Budhi GS, Kuswanto SA and lqbal M. 2008. Concept and implementation of PES Program in the Cidanau watershed: A lesson learned for future environmental policy. Policy Analysis of Farming 6:37-55.

Conceicao HR. 2012. REDD+ and Poverty in the Brazilian Amazon: A Framing Perspective of Project Actions. Freiburg, Germany: AlbertLudwigs Universität.

Corbera E, Brown K and Adger WN. 2007. The equity and legitimacy of markets for ecosystem services. Development and Change 38(4): 587-613.

Corbera E, González Soberanis C and Brown K. 2009. Institutional dimensions of Payments for Ecosystem Services: An analysis of Mexico's carbon forestry programme. Ecological Economics 68:743-61.

Costanza R. 2008. Ecosystem services: Multiple classification systems are needed. Biological Conservation 141:350-52.

Cotula L and Mayers J. 2009. Tenure in REDD+ - Start-point or Afterthought? Natural Resource Issues No. 15. London: International Institute for Environment and Development

Engel S, Pagiola S and Wunder S. 2008. Designing payments for environmental services in theory and practice: an overview of the issues. Ecological Economics 65:663-74.

Fisher B, Turner RK and Morling P. 2009. Defining and classifying ecosystem services for decision making. Ecological Economics 68:643-53.
Galudra G, Van Noordwijk M, Suyanto S, Sardi I, Pradhan U and Catacutan D. 2011. Hot spots of confusion: Contested policies and competing carbon claims in the peatlands of central Kalimantan. International Forestry Review 13(4):431-41.

Goldman-Benner RL, Benitez S, Boucher T, Calvache A, Daily G, Kareiva P, Kroeger T and Ramos A. 2012. Water funds and payments for ecosystem services: practice learns from theory and theory can learn from practice. Oryx 46:55-63.

Gomez-Baggethun E and Ruiz Perez M. 2011. Economic valuation and the commodification of ecosystem services. Progress in Physical Geography 35:613-28.

Hall A. 2008. Better RED than dead: Paying the people for environmental services in Amazonia. Philosophical Transactions of the Royal Society B 363:1925-32.

Indrarto GB, Murharjant P, Khatarina J, Pulungan I, Ivalerina F, Rahman J, Prana MN, Resosudarmo IAP and Muharrom E. 2012. The Context of REDD+ in Indonesia. Working Paper 108. Bogor, Indonesia: CIFOR.

Karsenty A, Vogel A and Castell F. 2014. "Carbon rights", REDD+ and payments for environmental services. Environmental Science and Policy 35:20-29.

Krause T and Loft L. 2013. Benefit distribution and equity in Ecuador's Socio Bosque program. Society and Natural Resources: An International Journal 26:1170-84.

Laurans Y, Lemenager T and Aoubid S. 2012. Payments for Ecosystem Services. From Theory to Practice - What are the Prospects for Developing Countries? Paris: Agence Française de Développement (AFD).

Leimona B, Pasha R and Rahadian NP. 2010. The livelihood impacts of incentive payments for watershed management in Cidanau watershed, West Java, Indonesia. In Tacconi L, Mahanty S and Suich H, eds. Payments for Environmental Services, Forest Conservation and Climate Change - Livelihoods in the REDD? Cheltenham, UK: Edward Elgar. 106-29.

Leimona B, Boer R, Arifin B, Murdiyarso D and van Noordwijk M. 2006. Singkarak: Combining Environmental Service Markets for Carbon and Watershed Functions? In Murdiyarso D and Skutsch M, eds. Community Forest Management as a Carbon Mitigation Option: Case Studies. Bogor, Indonesia: CIFOR. 60-73.

Lindhjem H, Aronsen I, Bråten KG and Gleinsvik A. 2010. Experiences with Benefit Sharing: Issues and Options for REDDplus. Oslo: Econ Pöyry.

Loft L, Andersson K and Mwangi E. 2014. Carbon rights in potential REDD+ countries. (Unpublished manuscript).

Lopa D, Mwanyoka I, Jambiya G, Massoud T, Harrison P, EllisJones $\mathrm{M}$, Blomely $\mathrm{T}$, Leimona $\mathrm{B}$, van Noordwijk $\mathrm{M}$ and Burgess N. 2012. Towards operational payments for water ecosystem services in Tanzania: A case study from the Uluguru Mountains. Oryx 46(1):34-44.

Luttrell C, Loft L, Gebara MF, Kweka D, Brockhaus M, Angelsen A and Sunderlin W. 2013. Who should benefit from REDD+? Rationales and realities. Ecology and Society 18(4):52.

Luttrell C, Loft L, Gebara MF and Kweka D. 2012. Who should benefit and why? Discourses on REDD+ benefit sharing. In Angelsen A, Brockhaus M, Sunderlin WD and Verchot LV, eds. Analysing REDD+: Challenges and Choices. Bogor, Indonesia: CIFOR. 129-52.

Miteva DA, Pattanayak SK and Ferraro PJ. 2012. Evaluation of biodiversity policy in-struments: what works and what doesn't? Oxford Review of Economic Policy (28): 69-92. 
Munawir and Vermeulen S. 2007. Developing Markets for Watershed Services and Improved Livelihoods - Fair Deals for Watershed Services in Indonesia. Natural Resource Issues No. 9. London: International Institute for Environment and Development.

Muradian R, Arsel M, Pellegrini L, Adaman F, Aguilar B, Agarwal B, Corbera E, Ezzine de Blas D, Farley J, Froger G, Garcia-Frapolli E, Gómez-Baggethun E, Gowdy J, Kosoy N, Le Coq JF, Leroy P, May P, Méral P, Mibielli P, Norgaard R, Ozkaynak B, Pascual U, Pengue W, Perez M, Pesche D, Pirard R, Ramos-Martin J, Rival L, Saenz F, Van Hecken G, Vatn A, Vira B and Urama K. 2013. Payments for ecosystem services and the fatal attraction of winwin solutions. Conservation Letters 6(4): 274-279.

Muradian R, Corbera E, Pascual U, Kosoy N and May PH. 2010. Reconciling theory and practice: An alternative conceptual framework for understanding payments for environmental services. Ecological Economics 69:1202-208.

Naidoo R and Ricketts TH. 2006. Mapping the economic costs and benefits of conservation. PLoS Biology 4(11):2153-64.

Nelson F, Foley C, Foley LS, Leposo A, Loure E, Peterson D, Peterson M, Peterson T, Sachedina H and Williams A. 2009. Payments for ecosystem services as a framework for community-based conservation in northern Tanzania. Conservation Biology 24:78-85.

[OECD] Organisation for Economic Co-operation and Development. 2010. Paying for Biodiversity - Enhancing the Costeffectiveness of Payments for Ecosystem Services. Paris: OECD.

Pagiola S. 2008. Payments for environmental services in Costa Rica. Ecological Economics 65:712-24.

Pagiola S and Bosquet B. 2009. Estimating the costs of REDD at the country level. Forest Carbon Partnership Facility. www. forestcarbonpartnership.org/fcp/sites/forestcarbonpartnership. org/files/The\%20Costs\%20of\%20REDD\%2004-09-09.pdf

Pagiola S and Platais G. 2007. Payments for Environmental Services: From Theory to Practice. Washington, DC: World Bank.

Pagiola S, Arcenas A and Platais G. 2005. Can payments for environmental services help reduce poverty? An exploration of the issues and the evidence to date from Latin America. World Development 33:237-53.

Pattanayak SK, Wunder S and Ferraro PJ. 2010. Show me the money: do payments supply environmental services in developing countries? Review of Environmental Economics and Policy 4:254-74

Pereira S. 2010. Payment for environmental services in the Amazon Forest: how can conservation and development by reconciled? Journal of Environment and Development (19): 171-190.

Peskett L. 2011. Benefit Sharing in REDD+Exploring the Implications for Poor and Vulnerable People. Washington, DC: World Bank and REDD-net.

Pham T, Brockhaus M, Wong G, Dung LN, Tjajadi JS, Loft L, Luttrell C and Assembe Mvondo S. 2013a. Approaches to Benefit Sharing: A Preliminary Comparative Analysis of 13 REDD+ Countries. Working Paper 108. Bogor, Indonesia: CIFOR.

Pham TT, Bennett K, Phuong VT, Brunner J, Dung LN and Tien ND. 2013b. Payments for Forest Environmental Services in Vietnam: From Policy to Practice. Brief No. 22. Bogor, Indonesia: CIFOR. Pham TT, Campbell BM, Garnett S, Aslin H and Hoang MH. 2010. Importance and impacts of intermediary boundary organisations in facilitating payment for environmental services in Vietnam. Environmental Conservation 37:64-72.

Pham TT, Campbell MB and Garnett S. 2009. Lessons for propoor payment for environmental services: An analysis of the payment for environmental services projects in Vietnam. Asian Pacific Journal of Public Administration 31:117-35.

Pirard R and Billé R. 2010. Payments for Environmental Services (PES): A reality check - Stories from Indonesia. IDDRI Analysis 03/10. http://www.iddri.org/Publications/Collections/Analyses/ AN_1003_Pirard\%20Bille_PES\%20Indonesia.pdf

Rodriguez LC, Pascual U, Muradian R, Pazmino N and Whitten S. 2011. Towards a unified scheme for environmental and social protection: Learning from PES and CCT experiences in developing countries. Ecological Economics 70:2163-74.

Rørstad PK, Vatn A and Kvakkestad V. 2007. Why do transaction costs of agricultural policies vary? Agricultural Economics 36:1-11.

Spergel B and Taïeb P. 2008. Rapid Review of Conservation Trust Funds. 2nd ed. Washington, DC: Conservation Finance Alliance.

Tan NQ. 2011. Payment for Environmental Services in Vietnam: An Analysis of the Pilot Project in Lam Dong Province.: Occasional Paper No. 5. Kamiyamaguchi, Japan: Institute for Global Environmental Strategies Forest Conservation Project.

To PX, Dressler WH, Mahanty S, Pham $T$ T and Zingerli C. 2012. The prospects for payment for ecosystem services (PES) in Vietnam: A look at three payment schemes. Human Ecology 40: 237-49.

UN-REDD Programme. 2011. UN-REDD Programme social and environmental principles and criteria. Version 3 - draft for consultation. September 2011. The United Nations Collaborative Programme on Reducing Emissions from Deforestation and Forest Degradation in Developing Countries. Accessed 20 May 2012. http://www.un-redd.org/Multiple_ Benefits_SEPC/tabid/54130/Default.aspx.

Vatn A. 2010. An institutional analysis of payments for environmental services. Ecological Economics 69:1245-52.

Vatn A, Barton DN, Lindhjem H, Movik S, Ring S, Santos R. 2011. Can Markets Protect Biodiversity? An Evaluation of Different Financial Mechanisms. Noragric Report No. 60. Aas, Norway: Department of International Environment and Development Studies, Noragric.

Wertz-Kanounnikoff S and Angelsen A. 2009. Global and national REDD+ architecture: Linking institutions and actions. In Angelsen A, ed.. Realising REDD+ National Strategy and Policy Options. CIFOR: Bogor, Indonesia. 13-24.

Wunder S. 2005. Payments for Environmental Services: Some Nuts and Bolts. Occasional Paper No. 42. Bogor, Indonesia: CIFOR.

Wunder S. 2007. The efficiency of payments for environmental services in tropical conservation. Conservation Biology 21:48-58.

Wunder S, Engel S and Pagiola S. 2008. Taking stock: A comparative analysis of payments for Ecosystem services programs in developed and developing countries. Ecological Economics 65:834-52.

Wunder S and Alban M. 2008. Decentralized payments for environmental services: The cases of Pimampiro and PROFAFOR in Ecuador. Ecological Economics 65:685-98.

Wünscher T, Engel S and Wunder S. 2008. Spatial targeting of payments for environmental services: a tool for boosting conservation benefits. Ecological Economics 65:823-834. 


\section{Annex: PES case studies in focus countries}

We conducted an ISI Web of Knowledge search using the complementary search terms "payments for environmental services" and "payments for ecosystem services," yielding a total of 467 articles for the period 2005-2012. The articles were sorted into conceptual and case study papers. To identify case studies for our focus countries, the search terms were combined with the name of each focus country ("payments for environmental services" + "country name"). The search yielded 6 case studies for Vietnam, 7 for Tanzania, 1 for Cameroon, 22 for Brazil, 17 for Indonesia and 7 for Peru. A rapid analysis of these cases was conducted to select only those studies that covered practical experiences from actual implementation. We thereby excluded discussions of design only and theoretical articles in the preimplementation phase. Furthermore, studies that did not provide sufficient information on the outlined criteria for this assessment were excluded. Additional expert interviews were conducted to include gray literature reports for cases in Vietnam and Indonesia.

Table 1. Overview of case studies used for in-depth analysis.

\begin{tabular}{lll}
\hline Country & Case study & References \\
\hline Tanzania & $\begin{array}{l}\text { Equitable Payments for Watershed Services (EPWS) } \\
\text { program in the Uluguru Mountains }\end{array}$ & Branca et al. (2012), Lopa et al. (2012) \\
\hline Tanzania & $\begin{array}{l}\text { Terrat in the Simanjiro plains, east of Tarangire } \\
\text { National Park }\end{array}$ & Nelson et al. (2009) \\
\hline Vietnam & Son La Province & To et al. (2012), Pham et al. (2014 unpubl.) \\
\hline Vietnam & Lam Dong Province & To et al. (2012), Tan (2011) \\
\hline Indonesia & Cidanau & Leimona et al. (2010), Budhi et al. (2008), Munawir and \\
\hline Indonesia & Singkarak & Vermeulen (2007), Pirard and Billé (2010) \\
\hline Brazil & Bolsa Floresta & Pirard and Billé (2010), Leimona et al. (2006) \\
\hline Brazil & Proambiente & Pereira (2010), Conceicao (2012) \\
\hline
\end{tabular}

Table 2. Scale and level of governance and actors involved.

\begin{tabular}{|c|c|c|c|c|c|c|}
\hline Case study & Ecosystem service & $\begin{array}{l}\text { Level of } \\
\text { benefits }\end{array}$ & $\begin{array}{l}\text { Level of } \\
\text { implementation }\end{array}$ & $\begin{array}{l}\text { Ecosystem } \\
\text { service providers }\end{array}$ & $\begin{array}{l}\text { Ecosystem service } \\
\text { beneficiaries }\end{array}$ & Intermediaries \\
\hline EPWS & $\begin{array}{l}\text { Hydrological, soil } \\
\text { protection, crop } \\
\text { productivity as } \\
\text { a consequence } \\
\text { of gains in soil } \\
\text { conservation and } \\
\text { improved fertility }\end{array}$ & Local & $\begin{array}{l}\text { Local-regional } \\
\text { (villages in } \\
\text { Morogoro region) }\end{array}$ & $\begin{array}{l}\text { Village (upstream } \\
\text { farmers) }\end{array}$ & $\begin{array}{l}\text { Downstream } \\
\text { water users } \\
\text { (public water } \\
\text { utility DAWASCO, } \\
\text { private water } \\
\text { bottling company } \\
\text { Coca Cola Kwanza } \\
\text { Limited) }\end{array}$ & $\begin{array}{l}\text { NGOs (CARE, WWF); } \\
\text { Village Council }\end{array}$ \\
\hline Terrat & $\begin{array}{l}\text { Wildlife conservation } \\
\text { area (habitat } \\
\text { provision) }\end{array}$ & $\begin{array}{l}\text { Local- } \\
\text { global }\end{array}$ & Village & $\begin{array}{l}\text { Village (local } \\
\text { pastoralist) }\end{array}$ & $\begin{array}{l}\text { Consortium } \\
\text { of tourism } \\
\text { companies }\end{array}$ & - \\
\hline Son La & $\begin{array}{l}\text { Prevention of soil } \\
\text { erosion; sediment } \\
\text { reduction }\end{array}$ & Local & Province & $\begin{array}{l}\text { Forest owners } \\
\text { (mainly local } \\
\text { households) }\end{array}$ & $\begin{array}{l}\text { Two hydropower } \\
\text { companies, one } \\
\text { water supply } \\
\text { company }\end{array}$ & $\begin{array}{l}\text { Provincial authorities } \\
\text { (Provincial Son La } \\
\text { Forest Protection and } \\
\text { Development Fund, } \\
\text { managed by the } \\
\text { Provincial Department } \\
\text { of Agriculture and } \\
\text { Rural Development) }\end{array}$ \\
\hline Lam Dong & $\begin{array}{l}\text { Water regulation, } \\
\text { soil protection and } \\
\text { landscape beauty } \\
\text { preservation. }\end{array}$ & $\begin{array}{l}\text { Local } \\
\text { Global }\end{array}$ & Province & $\begin{array}{l}\text { State forest } \\
\text { companies and } \\
\text { management } \\
\text { boards, and local } \\
\text { communities } \\
\text { involved in } \\
\text { environmental } \\
\text { protection }\end{array}$ & $\begin{array}{l}\text { Two hydropower } \\
\text { plants, two water } \\
\text { supply agencies, } \\
\text { nine ecotourism } \\
\text { companies. }\end{array}$ & Provincial authorities \\
\hline
\end{tabular}


Table 2. Continue

\begin{tabular}{|c|c|c|c|c|c|c|}
\hline Case study & Ecosystem service & $\begin{array}{l}\text { Level of } \\
\text { benefits }\end{array}$ & $\begin{array}{l}\text { Level of } \\
\text { implementation }\end{array}$ & $\begin{array}{l}\text { Ecosystem } \\
\text { service providers }\end{array}$ & $\begin{array}{l}\text { Ecosystem service } \\
\text { beneficiaries }\end{array}$ & Intermediaries \\
\hline Cidanau & $\begin{array}{l}\text { Hydrology, } \\
\text { biodiversity, habitat }\end{array}$ & $\begin{array}{l}\text { Local, } \\
\text { global }\end{array}$ & Subdistrict & Four villages & PT KTI (hydrology) & $\begin{array}{l}\text { Forum Komunikasi } \\
\text { Cidanau (FKDC) - a } \\
\text { multi-stakeholder } \\
\text { forum }\end{array}$ \\
\hline Singkarak & Carbon sequestration & Global & District & $\begin{array}{l}\text { Community } \\
\text { representatives } \\
\text { and groups of } \\
\text { smallholders with } \\
\text { farming activities }\end{array}$ & $\begin{array}{l}\text { Foreign investor, } \\
\text { serving as an } \\
\text { intermediary for } \\
\text { the end buyers }\end{array}$ & $\begin{array}{l}\text { Local representatives, } \\
\text { research institutions }\end{array}$ \\
\hline $\begin{array}{l}\text { Bolsa } \\
\text { Floresta }\end{array}$ & Carbon storage & Global & $\begin{array}{l}\text { Federal State } \\
\text { (Amazonas) }\end{array}$ & Households & State of Amazonas & $\begin{array}{l}\text { The state of Amazonas } \\
\text { created FAS, a private } \\
\text { nongovernmental } \\
\text { institution, which } \\
\text { aimed to be } \\
\text { independent of } \\
\text { political interests and } \\
\text { which managed this } \\
\text { program }\end{array}$ \\
\hline Proambiente & $\begin{array}{l}\text { Reduction or } \\
\text { avoidance of } \\
\text { deforestation; carbon } \\
\text { sequestration; } \\
\text { recuperation } \\
\text { of ecosystem } \\
\text { hydrological } \\
\text { functions; soil } \\
\text { conservation; } \\
\text { preservation of } \\
\text { biodiversity; and } \\
\text { reduction of forest } \\
\text { fire risks. }\end{array}$ & $\begin{array}{l}\text { Local, } \\
\text { regional, } \\
\text { global }\end{array}$ & $\begin{array}{l}\text { A national (federal) } \\
\text { program to be } \\
\text { enacted by states. }\end{array}$ & $\begin{array}{l}\text { Households } \\
\text { (participating } \\
\text { families, small- } \\
\text { scale farmers, } \\
\text { indigenous } \\
\text { people) }\end{array}$ & $\begin{array}{l}\text { Federal } \\
\text { government }\end{array}$ & $\begin{array}{l}\text { Federal and state } \\
\text { organizations, } \\
\text { such as ministries } \\
\text { and specifically } \\
\text { established funds }\end{array}$ \\
\hline
\end{tabular}

Table 3. Activity rewarded and indicators for provision of ecosystem service.

\begin{tabular}{lll}
\hline Case Study & Activity rewarded & ES provision indicator \\
\hline EPWS & $\begin{array}{l}\text { Sustainable land management: e.g. afforestation, reforestation, } \\
\text { pineapple contours (with agroforestry and grass strips), kilaka } \\
\text { terraces (with agroforestry and grass strips), Fanya Juu terraces (with } \\
\text { grass strips), riparian restoration, sugarcane planting, tree planting. }\end{array}$ & Establishment of the agreed practices. \\
\hline Terrat & Prohibition on agriculture on the short-grass plains; Patrolling of area & Area not used for agricultural purposes \\
\hline Son La & Forest conservation and reforestation & Based on area and type of forest. \\
\hline Lam Dong & Forest conservation and reforestation & Based on area and type of forest. \\
\hline Cidanau & Tree planting and conservation & $\begin{array}{l}500 \text { trees/ha planted, plantings } \\
\text { maintained. }\end{array}$ \\
\hline Singkarak & Tree plantation and five years of best management practices & \\
\hline Bolsa & Forest conservation & $\begin{array}{l}\text { Yearly monitoring of deforestation level } \\
\text { would include in loco inspections and } \\
\text { Floresta }\end{array}$ \\
& & $\begin{array}{l}\text { satellite images; forest dwellers would } \\
\text { also monitor compliance with the } \\
\text { program }\end{array}$ \\
\hline
\end{tabular}


Table 4. Type and timing of benefits.

\begin{tabular}{|c|c|c|c|}
\hline Case study & Benefit type & Disbursement interval & Price setting \\
\hline EPWS & $\begin{array}{l}\text { Direct: cash USD 8-48/ha } \\
\text { Indirect: (expected) increase in farmer } \\
\text { incomes through increased crop } \\
\text { productivity; increased knowledge } \\
\text { and capacity of farming practices and } \\
\text { marketing, and the benefits of group } \\
\text { membership were additional incentives for } \\
\text { farmer participation } \\
\text { Further: EPWS staff provided training and } \\
\text { extension services. }\end{array}$ & $\begin{array}{l}\text { Transaction and implementation costs } \\
\text { covered by implementers upfront. } \\
\text { Annual payments: first year payments to } \\
\text { farmers released following appropriate } \\
\text { verification of establishment of the } \\
\text { agreed practices. } \\
\text { Further: Flat payment to village council } \\
\text { in the first project year for village } \\
\text { development projects. }\end{array}$ & $\begin{array}{l}\text { Unilaterally set by EPWS, } \\
\text { based on costs of input } \\
\text { activity }\end{array}$ \\
\hline Terrat & Cash & Annual payments & $\begin{array}{l}\text { Bilaterally negotiated } \\
\text { contract }\end{array}$ \\
\hline Son La & $\begin{array}{l}\text { Cash } \\
\text { In-kind: provision and upgrading } \\
\text { equipment for community hall } \\
\text { Other payments, i.e., mainly to create } \\
\text { microcredit schemes that allow poor } \\
\text { households to take out low-interest loans } \\
\text { for livelihood improvement projects }\end{array}$ & Annual payments & $\begin{array}{l}\text { Unilateral (top down) by } \\
\text { government Decision } \\
380: 10 \% \text { of the total } \\
\text { payment derived from } \\
\text { environmental service } \\
\text { buyers retained to cover } \\
\text { the administrative costs of } \\
\text { the government agency } \\
\text { managing the payment, } \\
\text { with the remaining } 90 \% \\
\text { to be allocated among } \\
\text { individuals, households or } \\
\text { rural communities - the } \\
\text { service providers. }\end{array}$ \\
\hline Lam Dong & $\begin{array}{l}\text { Cash (indirect payment as defined by } \\
\text { Decision 380) } \\
\text { Capacity building, and awareness raising } \\
\text { workshops at the village level for better } \\
\text { understanding of PES policy and the need } \\
\text { to conserve nature. } \\
\text { Further benefits included access to any } \\
\text { products in the forest that they invested } \\
\text { in from their own resources. Local } \\
\text { households were entitled to receive work } \\
\text { clothes for patrolling the forest. }\end{array}$ & Annual payments & $\begin{array}{l}\text { Unilateral (top down) by } \\
\text { government Decision } 380\end{array}$ \\
\hline Cidanau & Cash and capacity building & $\begin{array}{l}\text { First year: } 30 \% \text { paid on the signing of } \\
\text { the contract, } 30 \% \text { paid after six months } \\
\text { of implementation and the remaining } \\
40 \% \text { paid at the end of the year. } \\
\text { Subsequent annual payments: } 40 \% \\
\text { disbursed in June and } 60 \% \text { in December }\end{array}$ & $\begin{array}{l}\text { Prices are set during } \\
\text { negotiations between } \\
\text { the buyer (KTI), the } \\
\text { intermediary (FKDC) and } \\
\text { the sellers (farmer groups) }\end{array}$ \\
\hline Singkarak & Cash & $\begin{array}{l}60 \% \text { at the start, } 15 \% \text { following tree } \\
\text { plantation, then } 20 \% \text { in five years } \\
\text { provided the plantation has been } \\
\text { correctly managed, remaining } 5 \% \text { after } \\
10 \text { years }\end{array}$ & $\begin{array}{l}\text { Bilaterally negotiated } \\
\text { payment contracts: } \\
\text { between the Dutch investor } \\
\text { and local representatives, } \\
\text { and between local } \\
\text { representatives and } \\
\text { landowner groups }\end{array}$ \\
\hline $\begin{array}{l}\text { Bolsa } \\
\text { Floresta }\end{array}$ & $\begin{array}{l}\text { Cash and capacity building; subprograms } \\
\text { transferred reward payments to the } \\
\text { community in the form of initiatives } \\
\text { related to education, citizenship, health, } \\
\text { capacity building and infrastructure }\end{array}$ & $\begin{array}{l}\text { Monthly stipend payment to women; } \\
\text { yearly payment to communities }\end{array}$ & Unilateral \\
\hline Proambiente & $\begin{array}{l}\text { Cash and capacity building, i.e. technical } \\
\text { support }\end{array}$ & Monthly salary & Unilaterally set by state \\
\hline
\end{tabular}


Table 5. Role of intermediaries in benefit distribution.

\begin{tabular}{lll}
\hline Case Study & Intermediary & Obligations \\
\hline EPWS & $\begin{array}{l}\text { The EPWS project unit in Morogoro and an } \\
\text { intermediary group composed of influential } \\
\text { government officers in Dar es Salaam. }\end{array}$ & $\begin{array}{l}\text { Prepared business cases for companies in Dar es Salaam, negotiated } \\
\text { memoranda of understanding with major water users, and developed } \\
\text { the mechanism for disbursing funds }\end{array}$ \\
\cline { 2 - 3 } & CARE and WWF & $\begin{array}{l}\text { As implementers, bringing together buyers and sellers (facilitating } \\
\text { agreement between DAWASCO and CARE for payments for service } \\
\text { delivery, and between CARE and village authorities concerning terms } \\
\text { for payment) }\end{array}$ \\
\cline { 2 - 3 } & Provision of funding for establishment \\
\cline { 2 - 3 } & Danish and Dutch government & $\begin{array}{l}\text { Training partners and monitoring activities, transfer of payments } \\
\text { from village authorities to farmers }\end{array}$ \\
\hline
\end{tabular}

Terrat

Son La

\begin{abstract}
Provincial Forest Protection and Development Fund (FPDF) managed by the Provincial Department of Agriculture and Rural Development (DARD) and monitored by the Provincial Finance Department PES management boards are established at district, commune and village levels, consisting of representatives from DARD and from the departments of finance, planning and investment of the province and district and commune people's committees.
\end{abstract}

\begin{tabular}{ll}
\hline Lam Dong & Provincial authorities on the ground included \\
\hline Cidanau & $\begin{array}{l}\text { Multi-stakeholder Forum Komunikasi Cidanau } \\
\text { (FKDC) }\end{array}$
\end{tabular}

FKDC ad hoc team consisting of representatives of government institutions at the provincial and regency levels in the Cidanau watershed area and an NGO

\section{Multi-stakeholder Forum Komunikasi Cidanau}

Provides guidance and approves proposals on planning and implementation of PES

Monitors and verifies the quality of forests, signs contracts on forest protection with forest owners and distributes payments
Measurement of the economic value of ecosystem services; identification of buyers and sellers; establishment of organizational and institutional structures for the distribution of payments Manages funds, facilitates contracts with farmer groups, and monitors and verifies rehabilitation activities Also raise awareness of payments for environmental services among other potential buyers in the Cilegon industrial area

Facilitation of the scheme: (i) managing the payment of PES funds from the buyer to the farmers for their rehabilitation and conservation activities; (ii) supporting planting on private farms involved in the PES project; (iii) encouraging other potential buyers to join the scheme; and (iv) advocating the integration of the PES scheme in the provincial and district governments' environmental management policy

$\begin{array}{ll}\text { Singkarak } & \text { Local representatives } \\ \text { RUPES }\end{array}$

\begin{tabular}{ll}
$\begin{array}{l}\text { Bolsa } \\
\text { Floresta }\end{array}$ & $\begin{array}{l}\text { State of Amazonas created FAS, a private } \\
\text { nongovernmental institution, which aimed to be } \\
\text { independent of political interests. }\end{array}$ \\
\hline
\end{tabular}

Proambiente Federal and state organizations, such as ministries

and specifically established funds
Builds capacity of local communities by developing institutions at relevant scales.

Management of program; institutional stability and credibility, to attract funds.

This info brief is part of a series of reviews on existing literature and practices to derive relevant lessons for the design of REDD+ benefit sharing mechanisms. The reviews aim to stimulate debate on balancing effectiveness and efficiency, while ensuring equity in ongoing policy processes in the development of REDD+ as a performance-based mechanism.

\begin{tabular}{l|l} 
CGIAR & $\begin{array}{l}\text { RESEARCH } \\
\text { PROGRAM on } \\
\text { Forests, Trees and } \\
\text { Agroforestry }\end{array}$
\end{tabular}

This research was carried out by CIFOR as part of the CGIAR Research Program on Forests, Trees and Agroforestry (CRP-FTA). This collaborative program aims to enhance the management and use of forests, agroforestry and tree genetic resources across the landscape from forests to farms. CIFOR leads CRP-FTA in partnership with Bioversity International, CATIE, CIRAD, the International Center for Tropical Agriculture and the World Agroforestry Centre.
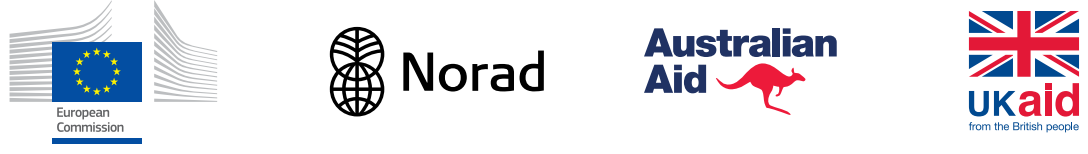

cifor.org 